\title{
De etterlattes stemme i biografiske og skjønnlitteraere tekster
}

Ved Kirsti A mundsen

\section{I de siste årene har det kommet ut flere bøker på norsk, svensk og dansk der etterlatte ved selumord} har vaert intervjuet. Felles for bøkene er at de etterlatte selv får komme til orde og fortelle om egne opplevelser og reaksjoner. Ofte kommenteres de etterlattes erfaringer au fagfolk. I denne artikkelen presenteres noen av disse bøkene, samt noen skjønnlitterœere tekster.

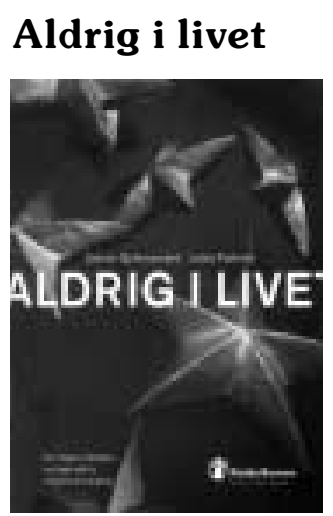

På slutten av 1990-tallet startet Rädda Barnen i Sverige sorggrupper for tenåringer som hadde mistet foreldre eller søsken i selvmord. N oen av disse ungdommenes opplevelser og erfaringer ble samlet i boka A ldrig i livet av psykolog G öran Gyllenswärd og sosionom Lotta Polfeldt. Her forteller de unge om hva som skjedde da de fikk vite om selvmordet, hvordan de reagerte, om forholdet til de andre i familien, hvordan det var å komme på skolen og treffe venner igjen, og om hvordan livet har gått videre.

M alin, 18 år, mistet faren sin i selvmord: I bland kändes det som att jag balanserade på en synål och inte visste åt vilket håll jag skulle falla. Jag visste inte vad som skulle hända. A tt min pappa dog påverkade alt. H ela mitt liv, min självbild, hela min syn på världen. $0 \mathrm{~m}$ det inte är självklart att ha livskraft och livsglädje, vad är då självklart? 0 m inte min pappa vill leva, vad kan inte hända då?

$\mathrm{H}$ ela min tilvaro blev helt förändrad. $M$ itt självförtroende sjönk. D elvis försvann min identitet, jag var ju inte längre pappas dotter. 0 ch när inget är självklart är det inte heller självklart att jag är bra på olika saker. För tänk om jag inte är det, tänk om alt faller...

Sanna, 19 år, mistet storesøsteren sin i selvmord:

V ad många som förlorat syskon funderar över är vilken "rätt" man egentligen har att sörja. M an ska förstå att det trots alt finns det som är värre. D et värsta man kan vara med om är inte att förlora ett syskon. D et är att förlora ett barn. M an făr høra att man är ung och har hela livet framför sig. Just därför, brukar jag svara. J ag har hela livet framför mig, jag ska leva hela mitt liv med förlusten. Jag ska ha tomrummet med mig hela livet.

D et finns en anna sak som är jobbig. Vad ska man svara på frågan hur många syskon man har? U nder en tid hade jag nästan fobi mot att träffa nya människor bara för att jag hade så svårt att vara uppriktig. A ntingen kan man ljuga och säga att man har tre syskon, eller så ljuga och säga att man har två, eller så säga som det är - att en av dem är död. N är kan man göra det? Inte på en fest i alla fall. $N$ är kan man prata om det över huvud taget?

I tillegg til de personlige historiene i boka henvender $G$ yllenswärd og Polfeldt seg direkte til unge etterlatte lesere med utdypende svar på spørsmål som: Varför? F inns det något svar? Var det mitt fell att han dog? F år man vara arg på den som dog? B lir man dum i huvudet av sorg? Kan jag vara bara som vanligt? K ompisarna? Fattar de ingenting? $M$ åste jag prata med någon?

A vslutningsvis gis det råd om hvordan en kan ta vare på minnene om avdøde.

\section{Vaer der for meg: om ungdom, død og sorg}

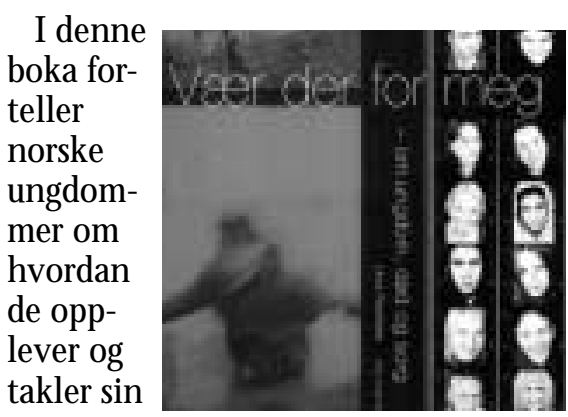

sorg etter

at en som sto dem nær, døde. Unni Ranheim har redigert boka, og gjennom sitt møte med ungdommene har hun erfart at de ikke krever så mye av sine venner og av oss voksne som vi kanskje tror. "De ønsker bare at vi skal vise dem at vi vet at de sørger og at vi respekterer deres sorg. De vil at vi skal se dem, være oppmerksomme mot dem, huske på dem, rett og sl ett bare være der for dem."
M erete, 23 år, mistet bestevenninnen sin i selvmord da hun var 16 år:

A da var leder i fritidsklubben vår. M ed henne kunne jeg snakke om alt. $\mathrm{H}$ un forsto at jeg var sinna, og hun aksepterte det. $\mathrm{N}$ oen blir sinna, sa hun, og det har du blitt. I tida etter begravelsen følte jeg meg helt alene i hele verden. A ldri har jeg følt meg så ensom og forlatt noen gang. Jeg vet ikke hva jeg skulle ha gjort uten $A$ da, verken da eller senere. F ortsatt har vi god kontakt.

A It kommer ikke på en gang. Det er akkurat som om kroppen sparer deg en stund. M ed det samme er det forferdelig, men så kommer du gjennom det. $M$ en så kommer det nye ting du ikke har tenkt på, som du også må gjennom. $\mathrm{H}$ adde du fătt alt på en gang, hadde du ikke klart det.

D et kan gå lange perioder uten at det er trist, men så kommer det opp igjen. D et vil alltid komme påminnelser, selv om det har gått mange år. $M$ en ingen må være redde for å komme med slike påminnelser. $\mathrm{H}$ vis du reagerer, viser det bare at det er noe du må jobbe mer med.

U like fagpersoner kommenterer ungdommenes historier og tar opp temaer som ensomhet ved sorg, ulike reaksjonsmåter blant gutter og jenter, det å få nye verdier, få lov til å være sint, føle lettel se og ritualer rundt døden

\section{Sorgen ved selvmord}

Journalist Inger A nneberg har alltid vært opptatt av hva som skjer i familier der taushet, fortielser og tabuer slår igjennom. $\mathrm{H}$ un ble interessert i temaet selvmord gjennom jobben sin og ønsket å gå i gang med et bokprosjekt om etterlatte ved sel vmord. I januar 2001 val gte hun som et forsøk å etterlyse etterlatte gjennom det danske bladet $\mathrm{H}$ else. Det resulterte i en overveldende respons. Flere enn 200 personer tok kontakt og ville bidra med sin historie, de fleste drevet av et meget sterkt ønske om at deres erfaringer skulle komme andre etterlatte til gode. 40 informanter ble valgt ut til å fortelle sin historie i boka. Ingen trakk seg underunderveis. 
For å kunne gi et hel hetlig bilde av de etterlattes situasjon valgte A nneberg å la de etterlatte fortelle om hva som

skjedde forut for selvmordet, i tillegg til selve dødsfal let og tida etterpå.

$U$ tval get av historier gjenspeiler til en viss grad det typiske ved selvmordsproblematikken i Danmark og også i N orge, dvs. at de fleste som tar livet sitt, har en psykisk lidelse, at eldre har høy selvmordsrate, at det er flest menn som tar sitt eget liv, og at kombinasjonen al koholmisbruk og psykisk lidelse er en alvorlig risikofaktor. Det er således egne kapitler om etterlattes forhold til psykiatrien og etterlatte ved gamle menneskers selvmord. Det er flest kvinnelige bidrag, og det er mange etterlatte som forteller at familien har måttet leve med dobbel te tabuer som psykisk sykdom og (alkohol) misbruk.

I innledningen sier A nneberg at hun har ett formål med boka: "A t give mæle til mennesker, der ofte bliver mødt med tavshed." H un håper at boka kan bidra til å utvide håpets grenser både hos de etterlatte og hos mennesker som overveier å ta sitt eget liv.

Intervjuene er plassert under tre hovedoverskrifter:

- Følelser og reaktioner

- Relationer

- De professionelle og de efterladte

Bokas styrke er at så mange aspekter belyses under hvert tema. U nder Følelser og reaktioner skildres hemmeligheter, taushet, fortielse, skyld og ansvar, motstridende følelser som håp, sinne og lettelse, forhold til barna og troens betydning.

A nneberg har valgt å fokusere på følgende former for relasjoner:

- foreldre som etterlatte ved barn og unges selvmord

- barn, unge og voksne som etterlatte ved foreldres selvmord

- etterlatte ved partnerens død

- etterlatte ved gamle foreldres selvmord - flere selvmord i familien.

A ndre relasjoner er nevnt under Følelser og reaktioner, som for eksempel det å miste en bror eller søster.
I bokas siste del er etterlatte hjel pere intervjuet. Vi får bl.a. møte en psykiater, en politiansatt, en prest og en frivillig. De forteller om pasienter/klienter som har tatt sitt eget liv, og om hvordan de har opplevd à arbeide både med selvmordstruete mennesker og med etterlatte ved selvmord. En rettsmedisiner er også intervjuet.

\section{Det som skjer}

Forfatteren A rne Sundelin mistet moren sin i selvmord i voksen alder. M oren var over 70 år da hun tok sitt eget liv. Sundelin har skrevet en roman om en barndom og et voksenliv preget av en mor som slet med å finne sin plass i tilværelsen. Slik starter boka:

For ti år siden tok min mor sitt eget liv. Jeg har ikke vært i stand til å skrive om det som skjedde. D et har vært en forbudt bok. Jeg har tenkt at hvis jeg skriver om hennekommer det til å skade min far. I blant har jeg forestilt meg at han ikke ville tåle det. J eg har trodd at det var derfor jeg ikke har skrevet om henne, men kanskje er det noe som er enda vanskeligere. $\mathrm{N}$ oe i hennes historie som rommer en skremmende forståelse av meg selv. Jeg skal skrive denne forbudte boken for meg selv. Jeg vil vite hvem hun var for meg. Da hun tok sitt eget liv, var det noe vi ikke kunne forhindre. D et var en kraft som syntes større enn oss selv.

Sundelin kan minnes at det alltid hvilte en dødstrussel over moren og sier det ikke var lett å leve sammen med en mor som så sel vmordet som en utvei. $H$ an prøver å finne en forklaring i hennes tidligere liv: H un hadde opplevd å få tre dødfødte barn, og faren hennes hadde tatt sitt eget liv. Da forfatteren ble født, var det som om han skulle skape meningen i tilværelsen for moren. $H$ un trodde lykken lå i det å få barn, men hun fant seg ikke til rette i kjernefamilien og vantrivdes som husmor. H eller ikke forsto hun seg på barn. Sundelin husker episoder som gjorde ham skrekkslagen,som f.eks da han som liten gutt kranglet med moren mens de gikk langs en vei og hun truet med å kaste seg foran neste møtende bil hvis han ikke holdt fred. $H$ an viser giennom episoder fra livet med moren, hvordan hun i stor grad hadde makten over og styrte livene til ham selv, broren og faren. $0 \mathrm{~g}$ dermed slet hun dem nesten ut. Sundelin gir en realistisk beskrivelse av hvordan det kan være å leve i en familie der mor er psykisk syk og suicidal, og oppsummerer situasjonen slik mot slutten av morens liv:

$0 \mathrm{~g}$ igjen begynte jeg å kjenne det ubehaget som jeg hadde opplevd under oppveksten: hun var i ferd med å ta over livet mitt. En måned før hun døde hadde jeg bestemt meg for å bryte med henne. J eg orket ikke mer av lidelsen hennes, orket ikke å se hjelpeløsheten hennes; fortvilelsen hennes var i ferd med å spise meg opp. J eg var nødt til å bli fri fra henne. $\mathrm{N}$ oe jeg aldri noensinne har kunnet bli.

A vslutningsvis făr vi lese om tiden etter selvmordet, hvordan faren og broren forholder seg til bokas manus, og om familiebilder og-minner.

\section{Pappa ville ikke leve}

Dette er en bildebok skrevet og illustrert av $M$ argaretha Runvik. Den handler om Pers tanker og opplevelser like etter at faren tok sitt eget liv. A It er som det pleier - men allikevel helt annerledes.

\section{Per, 5 år:}

Pappa er død.

M an kan si det sånn, men det er akkurat som om jeg snakker om en annen. $0 \mathrm{~m}$ pappaen til en annen.

F or en måned siden levde pappa, og nå er han død. Da var han her. $\mathrm{N}$ å er han borte, selv om han hele tiden fins inni meg.

[... ]

$\mathrm{H}$ an orket ikke å leve lenger, sier mamma. Ja, ikke det vanlige ordet "orke", du vet: ikke å orke å spise opp maten sin eller ikke å orke å løpe så langt, men et mye større "ikke orke". Et så stort at vi ikke forstår det. M amma prøver å forklare, og jeg prøver å forstå. J eg har tegnet mange tegninger om pappas død. I blant synes jeg det er lettere å tegne enn å snakke. M amma og jeg har limt inn tegningene i en stor bok som vi kaller "Boka om pappa". Der har vi skrevet ned alt som var koselig, så vi ikke skal glemme det. D et var jeg som fikk den idéen da vi hadde vært på sykehuset og sagt " ha det" til pappa. 
Per forteller

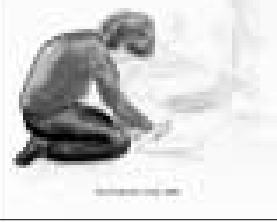
videre om hvordan både han selv og moren sørger over faren. $\mathrm{H}$ an forteller også om hvor-

dan det var å komme tilbake i barnehagen og snakke med kameratene om selvmordet.

$M$ ange konkrete spørsmål og funderinger som et barn kan ha, tas opp i boka. D erfor egner boka seg godt for høytlesning - som utgangspunkt for samtale. Bakerst i boka gis det råd til de voksne om hvordan man bør snakke med barna om døden, og da spesielt om selvmord. Det understrekes hvor viktig det er å fortelle barna sannheten og la dem ta del i sorgen.

\section{Med innsiden ut}

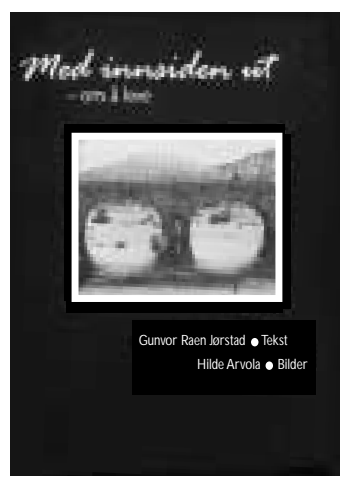

I denne boka formidler Gunvor Raen Jørstad og Hilde A rvola både livsglede og en uendelig stor sorg i sine tekster og bilder. De gir et klart svar på et spørsmål fylt med smerte:

$\mathrm{K}$ an et menneske som har mistet barnet sitt noensinne bli menneske igjen?

Ja.

$M$ en aldri, aldri det samme mennesket.

For kvinner som har opplevd en slik smerte, har Jørstad skrevet et eget kamprop. (Se høyre spalte på denne siden.)

Gjennom boka ønsker Jørstad og A rvola å vise at det som finnes på innsiden, også preger oss mennesker på utsiden.

\section{Avslutning}

Etter min mening er det svært positivt at det er kommet ut såpass mange bøker i det siste der etterlatte ved selvmord står i fokus. Det er et stort behov for disse bøkene. Det opplever jeg stadig gjennom hen ven del sene jeg får fra både etterlatte selv og fagfolk som spør etter aktuell litteratur om det å være etterlatt. Det er viktig å ha flere bøker å velge mellom og på den måten kunne henvise til litteratur som passer den enkeltes situasjon, enten det gjelder et ungt eller gammelt menneske. l eksemplene ovenfor har jeg forsøkt å ta med ulike innfallsvinkler for å vise hvor vidtfavnende bøkene er. For dem som møter etterlatte, enten det er gjennom jobben eller i andre sammenhenger, vil bøkene kunne gi verdifull kunnskap om og skape forståelse for hvordan det virkelig oppleves når en som står en nær, tar sitt eget liv. For etterlatte kan det være positivt å lese om andre som har opplevd det samme som en selv. A ndres erfaringer kan gi støtte og håp, og hjel pe de etterlatte til å komme seg videre i sorgarbeidet.

\section{Referanser}

A nneberg, Inger. Sorgen ved selvmord: en bog til de efterladte. København: $H ø$ st \& Søn, 2002 - 373 s. ISBN 87-14-29766-3

Gyllenswärd, G öran/Polfeldt, Lotta. A Idrig i livet: när någon i familjen har tagit sitt liv: ungdomar berättar. Stockholm: Rädda Barnen, 2001. - $94 \mathrm{~s}$ ISBN 91-89366-72-7. Kan bestilles fra utgiver: faks: 08-698 9010, e-post: info@rb.se, Internett: www.rb.se

Jørstad, G unvor Raen (tekst)/A rvola, Hilde (bilder). Med innsiden ut: om å leve. Egersund: Fuglseth, 2003. - 63 s. ISBN 82-996740-1-8

Ranheim, Unni (red.) V ær der for meg: om ungdom, død og sorg. - Vollen: Tell, 2002. - $107 \mathrm{~s}$. ISBN 82-7522-193-5

R unvik, M argaretha. Pappa ville ikke leve.

$O$ versatt av Kirsti A mundsen, råd og informasjon til voksne av $M$ argaretha R unvik, med etterord av Lars M ehlum. O slo: Seksjon for selvmordsforskning og -forebygging, 2003. U tgitt første gang på svensk i 1998. Kan bestilles fra utgiver (SSFF): www.selvmord.info, faks: 22923958.

Sundelin, A rne. D et som skjer. O versatt av Stig Sæterbakken. O slo: Bokvennen, 2001. - $126 \mathrm{~s}$.

U tgitt første gang på svensk i 1996.

ISBN 82-7488-116-8

\section{Ønsker du å lese mer?}

Litteraturliste med referanser til bøker, fag- og forskningsartikler mv. om etterlatte ved selvmord fins under www.selvmord.info - menypunkt Litteratur. $\mathrm{H}$ er fins det også en liste over skjønnlitteratur med selvmord som tema.

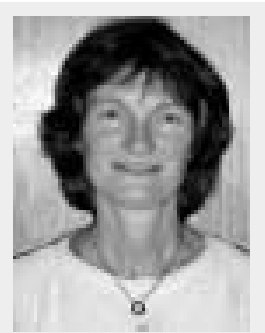

Kirsti A mundsen er informasjonskonsulent ved Seksjon for selvmordsforskning og -forebygging.

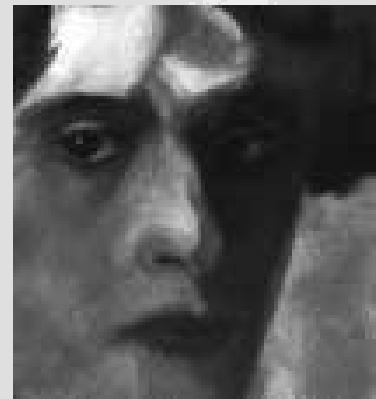

\section{Kamprop fra de mange tause kvinnene}

Kom, la oss reise oss! La oss rope høyt og skrike! La oss trampe i golvet og storme fram, og si at her er vi, mødrene til våre sønner og døtre som tok sine egne liv!

Her er vi som bar dem fram, og som fødte dem, og som så dem vokse opp.... en stund.

Her er vi som måtte se dem dø for egen hånd, og som nå bare har en grav å legge blomster på, på kirkegården.

La oss rette oss opp, og vise våre ansikter tydelig!

La oss se i øynene menneskene som går forbi, og holde fast på blikkene deres. La dem få se at vi gråter for våre døde barn.

La dem se at vi ikke har noen skam i oss, bare tårer og sorg. G unvor Raen Jørstad 